\title{
ANNUAL REPORTS AND ACCOUNTS
}

\section{Annual General Meeting}

The Annual General Meeting will be held at the Offices of the Zoological Society of London, Regent's Park, N.W. 1, on Wednesday, 29th April, 1964 , at 5.30 p.m.

The Marquess of Willingdon, President, in the Chair.

\section{AGENDA}

(1) Minutes of the Annual General Meeting, 1963.

(2) Presentation of the Auditors' Report.

(3) Discussion of the Auditors' Report.

(4) Presentation of the Council's Annual Report.

(5) Discussion of the Council's Annual Report.

(6) Election of Officers of the Society.

(7) Election of Members to fill vacancies on the Council.

\section{Notes}

(1) The Council's Annual Report and the Auditors' Report are given on pages 196-197.

(2) The Council recommend that the following shall be elected as Officers of the Society for 1964 :-

President: The Marquess of Willingdon.

Honorary Treasurer: Mr. I. D. Malcolmson.

(3) The following members of Council retire on 29th April, 1964, and are not eligible for re-election for one year :-

Dr. F. Fraser Darling.

Mr. James Fisher.

Mr. E. O. Shebbeare.

(4) The following have been appointed to fill vacancies on the Council and their names are submitted for confirmation :-

Mr. David Attenborough.

The Lord Craigton

Mr. R. C. Morris.

\section{ILLUSTRATED TALK}

(To follow immediately after the A.G.M.)

"The Ecology and Management of Hippopotamus in Uganda," by Dr. R. M. Laws. 


\section{ANNUAL REPORT FOR THE YEAR ENDING 31st DECEMBER, 1963}

On 11th December the Society achieved its Diamond Jubilee, having been founded, as the Society for the Preservation of the Fauna of the Empire, at a meeting held at the British Museum (Natural History) on 11th December, 1903. The occasion was celebrated by a dinner in the restaurant of the Zoological Society of London on 16th December, 1963, with the President, The Marquess of Willingdon, in the Chair. Mr. E. P. Field, a member of the Society for over forty years, proposed the health of the Society, and Dr. T. C. S. Morrison-Scott, Vice-Chairman of Council, responded. Afterwards a presentation was made to Lt.-Col. C. L. Boyle, who retired on 31st December, and to Mrs. Boyle. Lt.-Col. Boyle had been Secretary since the death of Mr. H. G. Maurice in May, 1950.

At the General Assembly of the International Union for Conservation of Nature at Nairobi in September, the Society was represented by Colonel and Mrs. Boyle, and also by Mr. R. S. R. Fitter, Secretarydesignate, and Mrs. Fitter, Editor-designate of ORYX. Before the General Assembly, Colonel Boyle conducted a meeting of the Survival Service Commission, from the Chairmanship of which he later retired. This meeting was also attended by Mr. and Mrs. Fitter. Colonel Boyle attended a meeting of the Executive Board of IUCN at Morges in May, and Mr. Fitter, who was appointed a member of the reconstituted Survival Service Commission, under the chairmanship of Mr. Peter Scott, attended the first meeting of its Action Group at Morges in November. For a report on the General Assembly at Nairobi see p. 154, and for one on the SSC see p. 157.

Following the Nairobi conference, the Society started two campaignsone against the fashion for clothing and other articles made from the skins of the spotted cats, with the aim of putting an end to the illicit trade in leopard and cheetah skins and the large-scale poaching which supplies it (see p. 155); and one against turtle soup to save the turtles of the world from over-exploitation.

News of the Society's small herd of Arabian Oryx will be found in a note on p. 143. The following statement of future policy on the capture of endangered species was agreed on by Council :-

The Fauna Preservation Society will discourage any attempt to capture for whatever purpose animals of any endangered species, if that attempt seems of itself likely to cause or add to the risk of the extermination of the species as a wild animal. The Society will be prepared to acquiesce in such action only in extreme cases where it is shown to the Society's satisfaction to be essential to ensure the continued existence of the species.

The Deer (England and Wales) Act, of which the Society was one of the sponsors, became law on 31st July. It provides for the first time a close season for wild deer in England and Wales, and regulates the use of weapons with which they may be shot. A Bill for the restriction of the import of rare animals, on which the Society had been working for the past three years, was adopted as a private member's Bill by Miss Harvie Anderson at the beginning of the 1963-64 Session and is due for consideration in April, 1964. 
Two numbers of ORYX were issued, instead of the usual three, the second being a double number. Important papers published during the year included surveys by Mr. E. P. Gee on the Indian wild ass and on the wildlife resources of Nepal, including the Great Indian Rhinoceros. The Society contributed $£ 196$ towards the expenses of Mr. Gee's visit to Nepal and the printing of his report.

The Society's films continued to be much in demand, more than eighty applications for them being received during the year.

A set of display cards of rare Asiatic animals was prepared from the illustrations used in Lee Talbot's "A Look at Threatened Species", published in ORYX in 1960 (see inside back cover).

At the Annual General Meeting on 29th April Mr. John Hillaby spoke on "A Foot Safari through Africa". There were four other general meetings : on 9th January three films new to the Society's film library were shown-" Southern Rhodesia Wild Life," "Safari South," and "Big Game Country." On 26th January Mr. E. P. Gee spoke on "Wildlife Preservation in Nepal and India"; on 29th October Mrs. Iris Darnton spoke on "Australian and Tasmanian Wildlife"; and on 13th November Mr. Tom Harrisson spoke on "The Future of the Orang-utan and Other Wild Animals in South-East Asia ".

At the end of the year the resignation of Mr. John Hillaby, Public Relations Officer since January, 1960, was received with regret.

\section{THE AUDITORS' REPORT}

To the Council and Members of the

Fauna Preservation Society.

4th March, 1964.

ACCOUNTS FOR THE YeAR ENDED 31ST DeCEMBER, 1963

We have completed the audit of the Books and Accounts of the Society for the year ended 31st December, 1963, and report thereon as follows :-

\section{General Purposes Account}

The Balance on this Account at the end of the year was $f_{172} 4 \mathrm{~s} .9 \mathrm{~d}$. after transferring $\ell_{1} 105$ from the Life Membership Fund, and deducting $£ 789$ 0s. 11d., being the excess of Expenditure over Income on the year's working.

The total donations received, amounting to $£ 869$ 0s. $1 d$., have been credited this year to this Account.

The excess of Expenditure over Income in the previous year was $£ 1,45410$ s. $11 d$.

\section{General Reserve Fund}

The Balance on this Fund at 1st January, 1963, was $£ 7,306$ 17s. $2 d$., to which has been added $£ 100$ in respect of a Legacy transferred from Income and Expenditure Account.

A transfer of $£ 7835 s$. $4 d$. has been made to this Fund to repay advances 
made to the "Operation Oryx" Fund, increasing the Balance at 31st December, 1963, to $£ 8,1902 s$. $6 d$.

\section{Number of Members ON THE RolL}

The number of Members on the Roll at 31st December, 1963, was 2,178 , made up as follows :-

Honorary Members
Life Members
Ordinary Members : $\quad \cdot \quad \begin{array}{r}467 \\ 1,687 \\ \hline 2,178 \\ \hline\end{array}$

This shows a decrease of 1 Honorary Member, 133 Ordinary Members, and an increase of 5 Life Members.

\section{LIFE MEMBERSHIP FUND}

The Balance standing to the credit of the Fund is now $f 6,345$. This is after crediting $£ 280$ in respect of Life Membership Subscriptions received during the year and transferring $£ 105$ to the General Purposes Account which represents the value of subscriptions of those Life Members whose membership ceased during the year.

\section{INVESTMENTS}

The total investments at 31st December, 1963, at Cost amounted to $£ 15,146$ 10s. 9d., and the Market Value at that date was $£ 15,959$ 19s. 11d., showing a net appreciation of $f 8139 s .2 d$.

\section{SURPLUS}

The surplus of Assets over Liabilities at the end of the year amounted to $£ 14,7077 \mathrm{~s}$. $3 d$., as compared with $£ 14,3222 \mathrm{~s}$. $10 d$. at the end of the previous year.

\section{"Operation NoaH" \\ Kariba Fund}

A donation of $£ 500$ was received during the year from the RSPCA, Overseas Fund, making a total $£ 8953 s$. $10 d$. which has been paid over to the National Resources Board of S. Rhodesia.

\section{"Operation Oryx"}

Donations of $£ 8554 s$. $1 d$. were received during the year, including $£ 8534 \mathrm{~s}$. $1 \mathrm{~d}$. from the World Wildlife Fund, to meet expenditure paid from the Society's General Account in 1962. Net expenditure of $£ 69$ 18s. 9d. was incurred and the remaining balance of $£ 7835$ s. $4 d$. was transferred to General Reserve Fund in part repayment of advances made.

(Signed) W. B. KEEN \& Co.,

Chartered Accountants. 


\section{"Operation Oryx" \\ RECEIPTS AND PAYMENTS ACCOUNT}

FOR the YeAR to 31st December, 1963

Balance at 1st January, 1963-

$£$ s. $d . \quad £$ s. $d . \quad £$ s. $d$.

At Bank by General Reserve Fund.

Donations-

World Wildlife Fund

(Repaid to General Reserve Fund.)

Others .

Net Payment made to Major Grimwood

Administration Expenses . . . $2915 \quad 0$

$\begin{array}{lll}853 & 4 & 1\end{array}$

$2418 \quad 0$

Balance transferred to General Reserve
Fund.

\begin{tabular}{rrr}
67 & 1 & 9 \\
29 & 15 & 0 \\
\hline
\end{tabular}

$853 \quad 4 \quad 1$

$\begin{array}{lll}2 & 0 & 0\end{array}$

\begin{tabular}{llllll}
96 & 16 & 9 \\
\hline 950 & 0 & 10 & & & \\
880 & 2 & 1
\end{tabular}

\section{"Operation Noah"-Kariba Fund \\ RECEIPTS AND PAYMENTS ACCOUNT \\ For the Year to 31st December, 1963}

$£$ s. $d$.

Balance, 1st January, 1963

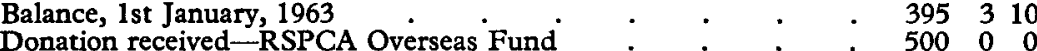

Donation received-RSPCA Overseas Fund . . . . $\quad \begin{array}{rrr}500 & 0 & 0\end{array}$

Payments to National Resources Board of S. Rhodesia . . . $\quad 895310$

- - -

We have examined the above Receipts and Payments Accounts with the books and accounts of the Funds and certify them to be in accordance therewith.

FinsBury Circus House,

W. B. KEEN \& CO.,

BLOMFIELD STREET,

LONDON, E.C. 2.

3rd March, 1964. 
INCOME AND EXPENDITURE ACCOUNT

GENERAL PURPOSES

1962

$£$

1,288

435

1,333

164

150

129

$\overline{274}$

250

19

100

79

26

94
To Salaries

„Public Relations Officer-Fees and Expenses

"Printing of Journal

"Printing and Stationery.

"Rent of Offices-

Regent's Park

Less Donation from Zoological Society

Other premises

, Office Expense

"Telephone

"Advertising

"Postage, etc.

"Films (Contribution to Production) . . . . do. Maintenance

"Assistant Secretary's PensionPremium .

"Accountancy and AuditAudit Fee, 1963. Accountancy, 1963 Income Tax Claim, 1963

"Subscriptions and DonationsInternational Council for Bird Preservation. Council for Nature

„Secretary's ExpensesAttending IUCN Meetings at Morges and Nairobi

"Secretary- and Editor-designate's Expenses-

Attending IUCN Meeting at Nairobi .

"Rhinoceros Survey-

E. P. Gee's Expenses .

Cost of Printing Report

„Educational Picture Cards and Posters

„Office Furniture and Fittings . f. s. d. $\quad$ s. $d$. $1,625 \quad 14 \quad 8$

$\begin{array}{lll}435 & 0 & 0\end{array}$

$1,384 \quad 9 \quad 0$

$\begin{array}{lll}229 & 6 & 7\end{array}$

$250 \quad 0 \quad 0$

$250 \quad 0 \quad 0$

$\overline{40} \overline{19} \overline{0}$

$\begin{array}{lll}40 & 19 & 0\end{array}$

240125

$\begin{array}{llll}47 & 6 & 11\end{array}$

$\begin{array}{lll}46 & 13 & 0\end{array}$

$\begin{array}{llll}321 & 6 & 5\end{array}$

$\overline{28} \overline{6} \overline{0}$

$523 \quad 6 \quad 9$

$\begin{array}{lll}31 & 10 & 0\end{array}$

$\begin{array}{lll}31 & 10 & 0\end{array}$

$\begin{array}{lll}26 & 5 & 0\end{array}$

$\begin{array}{lll}89 & 5 & 0\end{array}$

$\begin{array}{lll}5 & 5 & 0\end{array}$

$\begin{array}{lll}1 & 0 & 0\end{array}$

$\begin{array}{lll}744 & 2 & 8\end{array}$

$\begin{array}{lll}400 & 0 & 0\end{array}$

$\begin{array}{lll}80 & 17 & 0\end{array}$

$\begin{array}{lll}115 & 7 & 9\end{array}$

$196 \quad 4 \quad 9$

$\begin{array}{lll}297 & 1 & 0\end{array}$

$\begin{array}{llll}213 & 11 \quad 5\end{array}$

$£ 6,869107$ 


\section{for the year ended 31st DECEMBER, 1963}

ACCOUNT

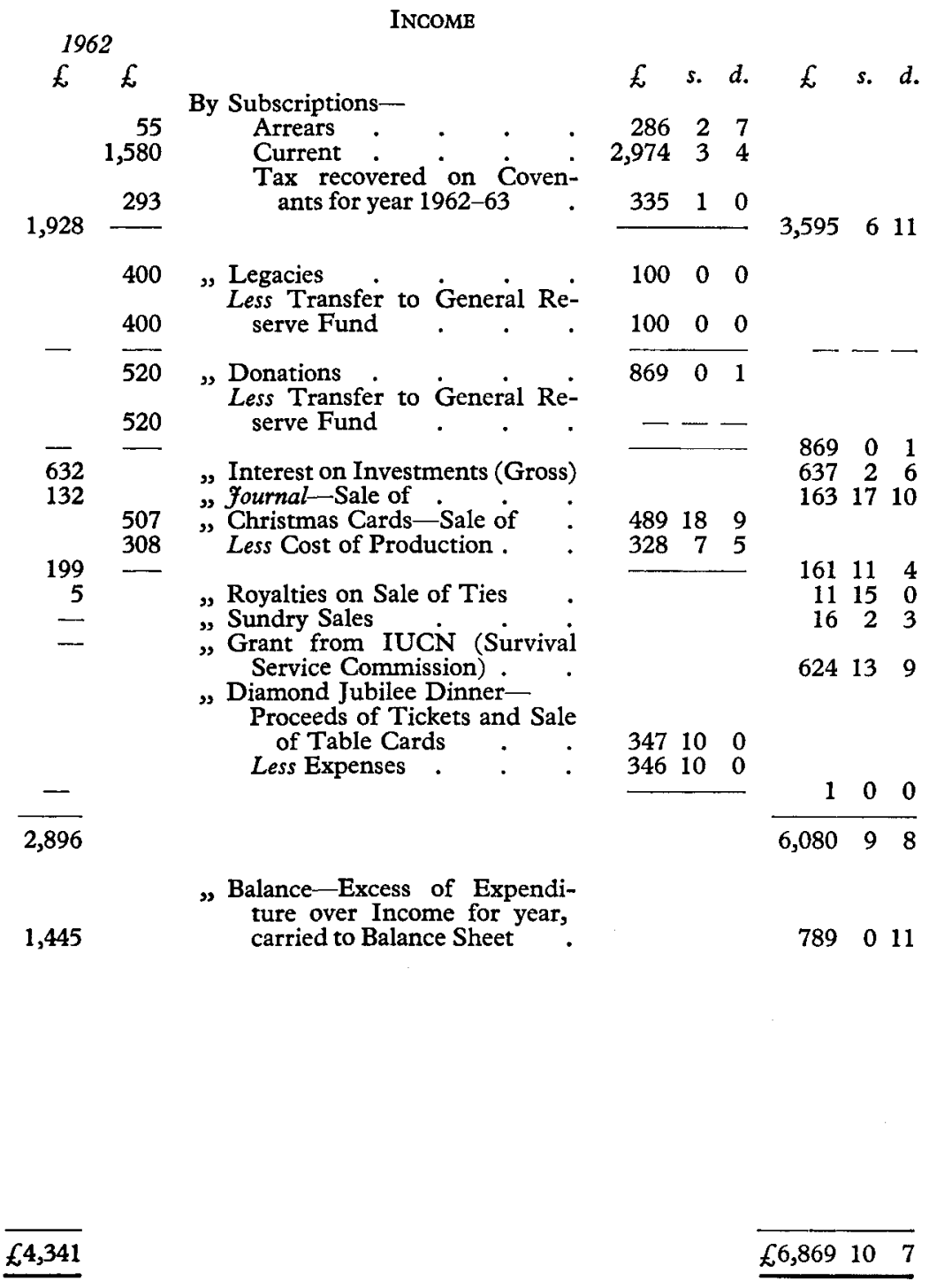




\section{BALANCE SHEET,}

1962

$\underset{1,431}{f} \in$
$\frac{232}{1,663}$

7,307

6,170

2,276

General Purposes Account -
Sundry Creditors
Receipts in Advance- Subscriptions

LIABILITIES

Balance, being Excess of Assets over

Liabilities :-

General Reserve Fund -

Balance at Ist January, $1963 \quad$. 7,306172

Add "Operation Oryx"

1962 Advance re-

paid per World

Wildlife Fund $\quad .853 \quad 4 \quad 1$

Less Net expenditure, $1963 \quad 69189$

Legacies transferred from Income and Expenditure Account

Life Membership Fund-

Balance at ist

January, $1963 \quad 6,170 \quad 0 \quad 0$

$A d d$ Fees received during year

28000

Deduct Transfer to General Purposes Account-

Subscriptions of deceased Life Members

Balance at 1st January, 1963

Add Transfer from Life Member-

$\frac{35}{2,311}$

$\begin{array}{r}856 \\ £ 15,996 \\ \hline\end{array}$

$\begin{array}{lll}783 & 5 & 4\end{array}$

$100 \quad 0 \quad 0$

$6,450 \quad 0 \quad 0$

$\begin{array}{lll}856 & 5 & 8\end{array}$

$\begin{array}{lll}105 & 0 & 0\end{array}$

96158

Deduct-

10 Loss on Sale of Investments . Excess of Expenditure over

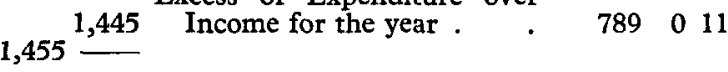

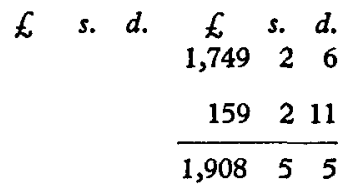

8,19026

$\begin{array}{llllll}105 & 0 & 0 & 6,345 & 0 & 0\end{array}$ 


\section{1st DECEMBER, 1963}

1962

\section{AssETs}

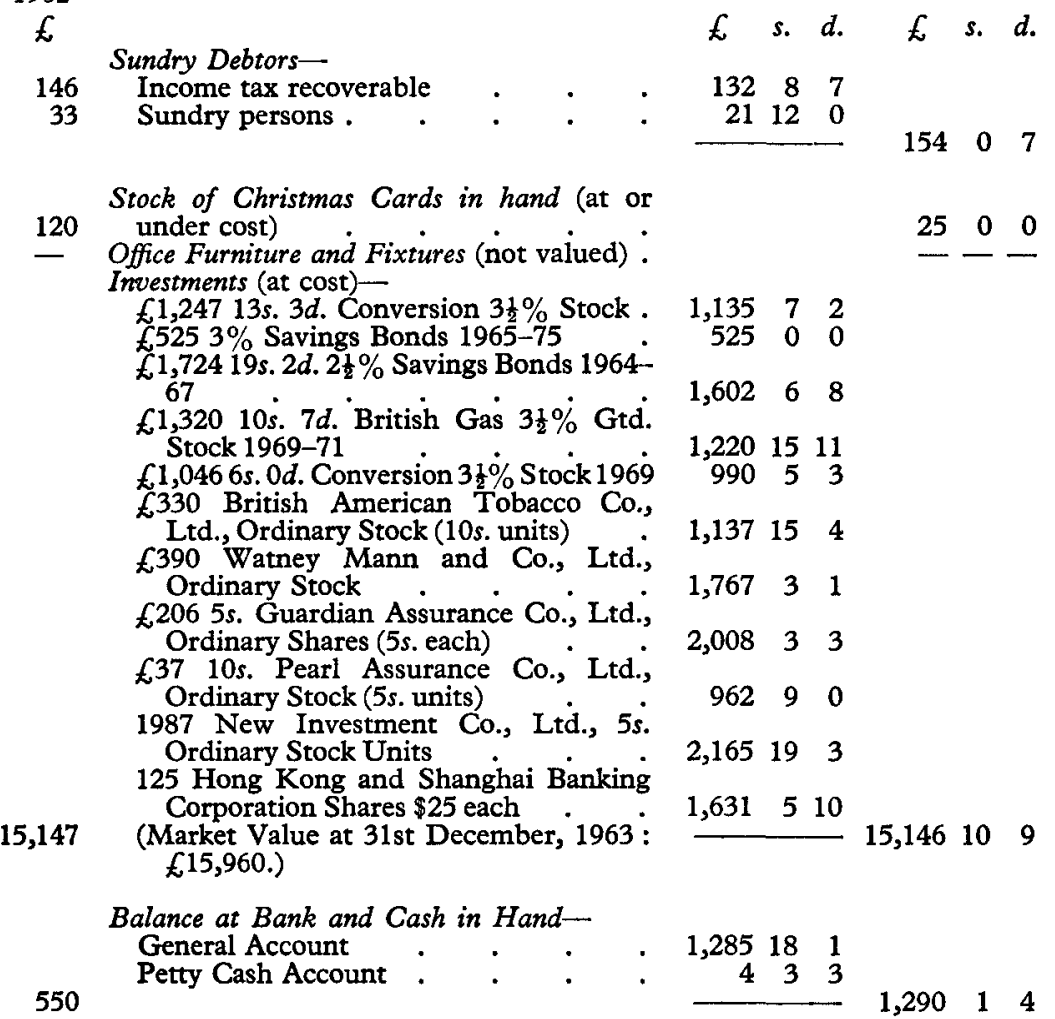

We have examined the above Balance Sheet and the accompanying Income and Expenditure Account with the books and Accounts of the Society and certify them to be in accordance therewith. We have verified the Bank Balance and the Investments of the various Funds.

FINSBURY CIRCUS House,

BLOMFIELD STREET, LONDON, E.C. 2.

W. B. KEEN \& CO.,

3rd March, 1964. 